For citation: Ekonomika regiona [Economy of Region]. - 2016. - Vol. 12, Issue 4. - pp. 1069-1078

doi 10.17059/2016-4-9

UDC 504.75, 911.375, 332.1

B. A. Revich ${ }^{\text {a) }}$, S. L. Avaliani ${ }^{\text {b) }}$, G. J. Simons ${ }^{\text {c) }}$

a) Institute of Economic Forecasting of the Russian Academy of Sciences (Moscow, Russian Federation; e-mail: brevich@yandex.ru)

b) Russian Medical Academy of Advanced Training (Moscow, Russian Federation)

c) Centre for Russian and Eurasian Studies of Uppsala University (Uppsala, Sweden)

\title{
AIR POLLUTION AND PUBLIC HEALTH IN A MEGALOPOLIS: A CASE STUDY OF MOSCOW
}

A rapidly growing number of megalopolises in the world leads to some substantial problems to environmental conditions of their population. One of these problems is the intensification of motor traffic, which contributes to air pollution measured as average concentrations of several air pollutants and climate change in the form of more frequent heat waves and cold spells. The present study analyzes the selected indicators of environmental health in Moscow, the largest Russian megalopolis which contributes for adoption of sound and evidence-based health risk management policies. Individual carcinogenic risks attributed to traffic emissions varied across the study area of $400 \mathrm{~km}^{2}$ between $3 \times 10^{-4}$ and $6.53 \times 10^{-4}$ which is typical for most megalopolises in the economically developed countries. However, the carcinogenic risks in some districts may exceed the threshold of $10^{-3}$ which is regarded as unacceptable. The total population carcinogenic risk for 3.5 million people who lived in the study area with intense road traffic was 23 additional cases of malignant neoplasms per year or 1513 cases per 70 years. Additional mortality during the extreme heat episode in the summer of 2010, when forest and peat fires caused exceptionally high levels of smog in Moscow, reached 11,000 deaths. The measures to be taken by the executive authorities include informing the residents about the onset of extreme heat by means of an early warning system, and rating the relative severity of heat and air pollution according to a 4-point scale.

Keywords: megalopolis, cities, Moscow, human ecology, environmental health, air pollution, risk assessment, climate change, heat waves, mortality

\section{Introduction}

An issue on the global agenda that has been of growing urgency and importance is the issue of climate change and its impact upon human health. This has been the subject of many international academic and political conferences and agreements. It has caused a great deal of controversy and breadth of debate - for and against. In March 2014, the Intergovernmental Panel on Climate Change (IPCC) released their report, which was on impacts, vulnerability, and adaption to climate change. The chapter 11 of the fifth report, human health: impacts, adaptation and co-benefits noted "health gains from strategies that are directed primarily at climate change and mitigation of climate change from well-chosen policies for health advancement." [1].

The issue of the possible effects of climate change as increasing vulnerabilities and as a security challenge to Russia has been of growing interest. In December 2014, President Vladimir Putin announced the National Technology Initiative

\footnotetext{
${ }^{1}$ (c) Revich B. A., Avaliani S. L., Simons G. J. Text. 2016.
}

(NTI) in the Federal Assembly. The purpose of its creation was clearly stated. "On the basis of longterm forecasting, it is necessary to understand what challenges will face Russia in 10-15 years, which innovative solutions will be required in order to ensure national security, quality of life, development of the sectors of the new technological setup (mode)" ${ }^{2}$. There is clearly an element of security concerns, especially as it relates to state security, human security and economic security. This has been witnessed in recent decades with weather extremes affecting Russia's largest city, Moscow, such as the increasing frequency and magnitude of the annual peat fires. Such occurrences compound the challenges for policy makers and planners, and adversely affect public health.

Moscow has been chosen as the focus of this study for a number of reasons. Firstly, it is the largest city in Russia and shares a number of climate and pollution problems with other megacities around the globe [2, 3, 4]. Secondly, there is

\footnotetext{
${ }^{2}$ National Technology Initiative. About the Project, Agency for Strategic Initiatives. Retrieved from: https://asi.ru/eng/nti/ (date of access: 07.06.2016).
} 
an appreciable effect on public health in Moscow, especially from sources of air pollution. Thirdly, there have been a number of changes in processes, for better and worse, in Moscow, that illustrates the importance and significance of this topic very well.

A significant threat posed by air pollution to public health is exacerbated by reduction of the quality of life, thereby increasing public expenditure on the treatment of those health issues and the loss of economic productivity, combined with increased public expenditure. When a country, such as Russia, faces a demographic crisis and an economic crisis simultaneously, an issue such as this one can rapidly be transformed into a security risk and threat. As such, it demands urgent attention and prudent policy in order to engage in the problem in a long-term and pro-active solution.

\section{Air pollution and public health in global debates}

The issue of pollution and its effects on public health in megalopolises are being discussed around the world widely [5]. A number of trends that have been occurring simultaneously have resulted in cumulative negative effects upon human health in large urban areas - the rapid process of urbanization, extensive energy consumption and high population growth. The detrimental effects touch the ecosystem, agriculture and human health. Carbon monoxide (CO) and nitrogen dioxide $\left(\mathrm{NO}_{2}\right)$ are among the leading offenders for air pollution and are highly hazardous to public health. One of the identified short-comings in current research on the societal costs of air pollution related ill-health is the need for more longitudinal data to better calculate the precise mortality and morbidity rates due to specific air pollution [6]. Health hazards should not be based upon monetary values, but also note the physical impacts (restricted human activity and loss of disability-adjusted life years).

Multiple pathways can be undertaken when designing and constructing a megalopolis, and the resulting built environment has potential impacts upon the health and well-being of its inhabitants. In dealing with the research challenges that are associated with the connections between the built environment and human health, Northridge et al note several key observations that need to be addressed. "1) The necessity of dealing with the possible health consequences of myriad public and private sector activities; 2) the lack of valid and reliable indicators of the built environment to monitor the health effects of urban planning and policy decisions, especially with regard to land use mix; and 3) the growth of the megalopolis or super urban region that requires analysis of health effects across state lines and in circumscribed areas within multiple states." They conclude that in order to plan effectively for healthy cities there needs to be a solid link established between urban planning and public health officials [7]. Even though, in some regards, the current state of being in megalopolis can be considered a crisis, it is also a potential opportunity. What is needed is a sense of political urgency and mobilization that is working towards an informed and scientific approach in order to address these problems.

A clear need exists in policy planning and implementation in this field, to determine cost estimates of the harmful health effects in order to establish and prioritize preventative health management actions. There is often a disproportionate burden of those afflicted by health issues among urban populations, especially among children and the elderly. In Sao Paulo, Brazil, the estimated (conservatively so) health cost attributable to air pollution at US\$ 3,222,676. An estimate of lost years of life in the city is put at 28,212 years $(12,266$ years from children and 15,946 from the elderly) [8]. The scale of this global problem is massive and even daunting, however, it is one that must and can be resolved if done intelligently.

\section{Russia's megacities and public health}

From a geographic standpoint, megacity is usually defined as a city with more than 10 million inhabitants, and some countries have witnessed the rapid growth of such cities. There is only one megacity in Russia: Moscow with population of more than 12 million. Yet, we suppose that many specificities and issues of megacities, being considered in this paper, have high significance for several other Russian megalopolises, such as Saint Petersburg, Yekaterinburg, Krasnoyarsk, Novosibirsk, Rostovon-Don and others.

The development of megalopolises has led to emergence of principally new human habitat, which affects public health in many ways, both positive and negative. Megalopolises have become a new research topic for urban studies, public health, regional economics, sociology, and cultural studies. The risks which new urban environment poses to its inhabitants, as well as baseline state of public health in a megalopolis, are important issues in environmental health science. The authors of the present study investigate some of these issues using the example of Moscow as the largest Russia's megalopolis.

There have been occurrences where different climatic and environmental factors have com- 
bined to produce significant public health hazards in Moscow. The spring of summer of 2010 illustrate this point, when prolonged hot weather and pollution that was caused from the wild fires outside of the city caused additional mortality. In this period, it is estimated that the death toll of the heat wave in the European part of Russia was as high as 55,000 . Therefore, it is essential to include the issue and prognosis of the effects of climate change upon public health, and especially in a megalopolis such as Moscow. Given Russia's human security challenge that is posed by the demographic situation of the country, concern should not focus primarily on raising birth rates, but to increase the quality and longevity of life for those current citizens.

\section{Medical and demographic indicators of public health}

Public (population) health in a megalopolis is influenced by complex demographic processes (intensive migration, including pendular migration (commuting), intra- and international migration, development of national enclaves, etc.). Moreover, megalopolises are characterized by specific environmental, social, and economic conditions, such as higher gross regional product, higher personal incomes, better education, intensive traffic load, etc. Consequently, baseline indicators of public health in a megalopolis may differ from national averages. We have observed these differences in Moscow, where life expectancy and mortality rates are closer to European standards than to values of the Russian national average. Mortality rates in Moscow have declined faster than nationwide in Russia. Standardized mortality coefficient (SMC) for Moscow males has declined by $41.9 \%$ between 2003 and 2014, whereas the same coefficient for all Russian males has declined by $32.7 \%$ during the same period. The corresponding decrements for females were $37.5 \%$ in Moscow and $29.2 \%$ in Russia nationwide. As a result, the gain in life expectancy during the same period in Moscow was greater than the national average. Life expectancy of Moscow males increased by 7.75 years while the corresponding national average increment was 6.65 years; the same values for females were 5.35 and 4.64 years, respectively. Morbidity rates have also decreased in Moscow between 2009 and 2014. Total morbidity rate among children decreased by $2.8 \%$ during this period; the corresponding decrement among adolescents and grown-ups were $12.6 \%$ and $15.8 \%$, respectively. These improvements are attributed to several reasons: relatively greater spending in public health sector in Moscow, better equipment in health diagnos- tics and screening facilities, a greater share of privately owned medical centers at workplaces and at the company level, higher levels of income and education, and other reasons of social and economic nature.

Several environment-dependent child diseases have shown even more significant decline in Moscow. For example, the number of respiratory diseases decreased by $14.2 \%$ between 2009 and 2014.

The structures of cause-specific mortality in Moscow and in Russia, in general, still remain quite similar $[9,10]$. The greatest portion of all deaths is attributed to diseases of circulatory system for both sexes. Nevertheless, the relative input of this group of causes of death gradually goes down. Between 2000 and 2014, the proportion of circulatory deaths among all deaths fell from $53.2 \%$ to $46.8 \%$ for males and from $60.4 \%$ to $53.6 \%$ for females. The second most important cause of death is malignant neoplasms for both sexes. The relative input of this cause increased by $3.6 \%$ for males and by $4.9 \%$ for females during the same period. The third most important group of causes of death in Moscow is external causes; their relative share in the structure of mortality remained almost constant during the same period.

Thus, the three most important causes of death in Moscow are diseases of circulatory system, accidents and malignant neoplasms. The number of deaths of Moscow males, attributed to the diseases of circulatory system, decreased by $24.2 \%$ between 2009 and 2014, and the corresponding decrement for Moscow females was $20.7 \%$. At the same time, the total number of diseases of circulatory system dropped by $9 \%$. This fairly positive trend coexists with the negative influence of environmental risks in megalopolises. In some cities, environmental health risks even increased. The relative input of environmental factors in total mortality is comparable to the inputs of such risks as genetic vulnerability and general state of medical care. Among environmental health risk factors in Moscow and other megalopolises air pollution is the most important, and it is mainly caused by emissions from road transport. In 2014, $94 \%$ of all air emissions in Moscow came from automobiles [11].

\section{Epidemiologic assessment of relationship between air pollution and public health in Moscow}

Direct epidemiologic studies of air pollution and health in Moscow began in the 1960s. Most of these studies were aimed at the identification 
of statistical relationships between children's health and air pollution from stationary and mobile sources in downtown Moscow. The results of these studies played an important role in hygienic, sanitary and environmental policy formulation, and provided scientific evidence for air pollution reduction efforts, the organization of an air pollution monitoring network and sometimes even led to phasing-out of certain polluting industrial enterprises. Environmental epidemiologists have provided sufficient evidence of statistical relationships between child asthma and emissions from metallurgic, perfume and several other types of factories. These factories have later been moved out of Moscow. Bronchial asthma of children is an important health endpoint (marker) which has been frequently used to establish statistical relationships between air pollution and health. One direct epidemiologic study conducted 20 years ago detected 110 hotspots where more than 100,000 children were exposed to particularly high risks of bronchial asthma [12]. During the last 12 years, the number of newly established asthma cases among children decreased by half, and total prevalence of children asthma decreased by $20 \%$ in Moscow. These trends were not observed on a national level. It is quite likely that certain improvements in air quality in Moscow have contributed to this positive trend. Indeed, significant downward trends in mean concentrations of several noxious air pollutants have been documented in Moscow. Mosecomonitoring (a municipal air quality monitoring service of the Moscow Environmental Protection Department) reported that annual average levels of nitrous dioxide in Moscow air have dropped by a factor of 4 , while $\mathrm{PM}_{10}, \mathrm{SO}_{2}$ and ozone levels have decreased by a factor of 2 since 2002. $\mathrm{PM}_{10}$ is an important indicator of air pollution and health effects $[13,14$, $15,16,17,18,19,20,21]$. However, a downward trend in $\mathrm{NO}_{2}$ concentrations has lately flattened off because of rapid growth in traffic intensity [12]. Despite certain positive trends in several indicators of environmental pollution, air pollution remains a problem in Moscow. Some territories of the city have shown significant increases in concentrations of air pollutants $\left(\mathrm{PM}_{10}, \mathrm{NO}_{2}\right.$, formaldehyde, polycyclic hydrocarbons) above 20-minute Federal air quality standards (maximum permissible levels, MPLs). Air quality seriously deteriorates on the days with unfavourable weather conditions, forest or peat fires. Apart from these natural phenomena, several anthropogenic factors also contribute to non-attainment of Federal air quality standards, such as continuous growth in the number of vehicles, poor technical condition of trucks and road-building machinery, operations of individual industrial facilities and power plants.

The territory of Moscow, just like the territory of any other megalopolis, resembles a mosaic where residential areas alternate with industrial areas and large industrial facilities, such as oil refineries, major waste water treatment plants, plants for the utilization of biological waste. It is from these hotspots that most residential complaints derive. The residents mostly complain about the bad smell. Children health indicators in industrial areas differ from those in the "background" of quiet residential areas. For example, external respiratory functions (forced vital capacity lung volume and volume of forced exhalation during the first second) of public school students between 6 and 12 years of age who lived in the two heavily polluted districts were significantly lower than those in the referent group. The decrements were estimated as $7.6 \%$ (95\% CI $3.6 \%-11.0 \%$ ) in one district and $9.9 \%$ (95\% CI $5.6 \%-14 \%)$ in the other district. This study took into account such confounding factors as age, sex and height of the children [22]. The place of residence can be an important risk factor, just like the smoking status of parents [23]. The main health risk factors (genetic vulnerability, passive smoking and dwelling next to the main motorways) similarly affect the development of bronchial asthma of children. The magnitude of the statistical relationship reaches 61-67\% [24]. The results of these and many other studies indicate the need to account for confounding factors in epidemiological studies. Confounding factors play an important role in assessment of relationships between environmental risk factors and public health. For example, one study established a significant relationship between morbidity of preschool children and such risk factors as the living area per one resident, education status of child's mother, professional health hazards as her workplace, whether or not the child began visiting pre-school institution earlier than two years of age, and mother's illness during pregnancy. The relative inputs of these risk factors were estimated as $3.9-12.5 \%$; 6.5-12.5\%; $3.8-8.9 \%$; $2.5-4.0 \%$ and $2.5-4.2 \%$, respectively [25]. During the last few years, several authors also investigated relationships between children health and air pollution levels in the place of residence. Higher levels of air pollution were associated with high level of anxiety, reduced indicators of short-term memory, reduced levels of cognitive development [26]. 


\section{Assessment of the relationship between heat waves, air pollution and mortality}

Climate change leads to an increase in the numbers of extremely hot and cold days, i.e., heat waves and cold spells. Climate experts predict increases in the number of days with extremely high temperatures, and increase in frequency of heat waves and heavy rainfalls. The Fifth IPCC Assessment Report mentioned that the period between 1983 and 2012 was, probably, the hottest 30 -year period during the last 1400 years in the Northern hemisphere. This report also predicted an increase in the mean global temperature. Heat waves and cold spells are defined individually for each climatic zone. Moreover, these definitions may differ for individual cities and particularly for megalopolises. The cities with different age structures and different levels of social and economic development are likely to have different temperature thresholds, even if situated in the same climatic zone. This hypothesis is currently validated during the analysis of the mortality of urban population in different European and African cities. From a public health perspective, it is very important to determine the heat threshold, above which the indicators of mortality increase or some other changes occur in the state of public health of representative population groups. In the same way, the cold threshold is defined as the temperature below which mortality rate increases.

The data from more than 50 European studies of mortality during summer heat periods showed that mortality is particularly high among senior people and particularly among patients with chronic diseases of the circulatory system, respiratory system, diabetes, people with limited mobility, bed-ridden patients, elderly single people [27]. Thus, all-cause mortality rate in Paris in the summer of 2003 was $60 \%$ higher than the average for the summers of 2000-2002 [28, 29]. The summer of 2003 in Europe was the hottest during the last 500 years. After this incident, French Public Health Ministry developed a special action plan for assessment and prevention of the acute influence of weather on public health. Similar action plans were developed and implemented in many countries and megalopolises. For example, a plan of adaptation of urban infrastructure to extreme weather conditions was developed in New York under the auspices of Mayor Michael Bloomberg ${ }^{1}$.

\footnotetext{
UNDP (2007). Human Development Report2007/2008 Fighting Climate Chance: Human Solidarity. In a Divided World, New-York, Palgrave Macmillan, 117. Retrieved from: http://hdr. undp.org/sites/default/files/reports/268/hdr_20072008_en_ complete.pdf (date of access: 07.06.2016).
}

The first study of the influence of temperature waves on mortality in Moscow was published in 2008 [30]. This study employed a time series analysis of daily mortality and air temperature for the period between 2000 and 2006. During the heat wave in July of 2001 in Moscow, daily mean temperatures exceeded $25^{\circ} \mathrm{C}$ for 9 consecutive days (the long-term average number of days above this threshold is only 3 days per year). During the peak of this heat wave, daily mortality in Moscow exceeded the respective long-term average value for July by $93 \%$. For comparison, daily mortality during the famous Chicago heat episode in 1993 was $85 \%$ higher than the background value. However, cumulative excess mortality (accumulated during the heat wave period) better measures the overall effect of the heat wave than the peak mortality rate. Cumulative excess mortality during a heat wave/cold spell can be calculated for each individual cause of death and age group, given the background value of mortality, which might be expected in the absence of this heat wave/cold spell. During such calculations, it is essential to account for a possible time lag between extreme temperature and its acute impact on mortality. The heat wave of 2001 in Moscow was associated with a pronounced and statistically significant peak in daily mortality in all age groups, and for all causes of death included in this study. It caused 1177 premature deaths in Moscow. The second heat wave included in this study occurred in the summer of 2002. It was less extended than the heat wave in 2001. Cumulative excess mortality during the heat wave in 2002 was estimated as 283 deaths which were roughly four times less than that in 2001.

The effects of extreme cold on mortality were observed in January and February of 2006, when an unusually long and severe cold wave occurred in Moscow, which lasted for 26 days. Such long waves happen only once in every ten years. The greatest health risk for the population of megalopolises is posed by concurrent effects of extreme heat and high levels of air pollution caused by forest and peat fires (themselves being the result of extended periods of hot weather). Wild fires produce large quantities of suspended particles in the air and thus contribute to $\mathrm{PM}_{10}$ pollution. The first evidence of combined effect of high temperatures and smog from wild fires on public health in Moscow was obtained in the summer of 2010, when prolonged period of extreme heat triggered peat fires near the city. Analysis of daily series of death counts in Moscow during this period helped measure combined (synergetic) effect of a heat wave and air pollution on mortality from several different causes. Daily mean number of deaths in 
Moscow is about 300 deaths, and statistical power of tests of significance of epidemiological model coefficients in daily time series studies can be very high. The heat wave in the summer of 2010 continued for 44 days, between July 6 and August 18. Daily mean temperature was above $30{ }^{\circ} \mathrm{C}$ and daily mean $\mathrm{PM}_{10}$ levels were above $300 \mathrm{mkg} / \mathrm{m}^{3}$ for several days during this period. Although previous studies have established a statistical relationship between air temperature, air pollution and mortality in Moscow, weather conditions have never been as extreme as in 2010. Daily mortality time series were used to calculate relative contributions of heat, air pollution and their interaction in excess mortality from all non-accidental causes during the heat wave of 2010 . The number of premature deaths from all non-accidental causes during the heat wave period reached 10860 , and the number of premature deaths from all external causes reached 181 . Summing these up, total excess mortality during the heat wave period in Moscow was 11041 deaths. The greatest relative risks of cause-specific mortality during the heat wave period were established for ischemia, respiratory diseases, diseases of the nervous and genitourinary systems, especially for kidney diseases. The relative risks of mortality of males and females were not statistically different [31].

Additional mortality among Moscow residents, caused by temperature waves and air pollution, led to economic losses. An estimated economic loss from excess mortality during the heat wave period of 2010 was between 97 and 123 billion roubles, which was equivalent to $1.23-1.57 \%$ of GDP [32].

Massive adverse consequences of extreme heat and air pollution episode in 2010 in Moscow created the demand for the development of an action plan which should be activated in case of such emergency situations. Such an action plan was developed and approved by Moscow Mayor. This plan advises that various departments of municipal Government: departments of public health, environmental protection, social development, transport, mass media and others take special measures for the protection of local residents. With the goal to provide economic justification for such measures, public health experts developed a 4-point scale to rate relative hazard of current meteorological conditions, and concentrations of $\mathrm{PM}_{10}$ and ozone. The hazard ratings $(1=$ low, $2=$ alarming, 3 $=$ medium and $4=$ high) were based on the results of health risk assessment of these adverse environmental factors. The relative risks were estimated using the methodology of time series analysis of daily mortality. This action plan included early warning system to inform Moscow residents about hazardous weather conditions and unusually high levels of air pollution.

Besides the official heat watch action plan, cardiologists have developed recommendations for patients with circulatory diseases. These recommendations specified a course of actions to take in the case of extreme heat: water consumption regime, use of air fans and air conditioners. Several medications which help adapt to extreme heat were tested in clinical epidemiologic studies. As a result, several preventive medications were selected and recommendations for use of these drugs were developed. It is very important that these recommendations are addressed not only to physicians but also to the general population. When information about extreme heat is received, these recommendations should be posted on the website of policlinic of Russian Cardiologic Centre ${ }^{1}$.

\section{Assessment of health impacts of air pollution using the methodology of risk assessment}

The successful application of a risk assessment methodology for the development of a strategy of various regulatory options with the goal to protect public health and improve the quality of human habitat permitted estimating potential and factual medical and social damage to public health in many Russian regions and particularly in Moscow. Based on the results of these studies, it became possible to identify the main risk factors and those population groups which were the most susceptible to the adverse influence of these factors. It also became possible to rank the territories according to the levels of health risks, not only for the current moment, but also for the future, using alternative scenarios of development of industries, energy sector, transport and all projected economic activities.

Health risk assessment for the residents of South-East municipal district of Moscow was conducted taking into account emissions from the main stationary sources, the oil refinery, a large power plant and road transport. Health risks caused by the emissions of car exhaust gases were estimated in 74 municipal districts of Moscow, in the zone of influence of automobile emissions along the motorways with intensive traffic.

Health risks of $\mathrm{PM}_{10}, \mathrm{PM}_{2.5}, \mathrm{SO}_{2}, \mathrm{NO}_{2}$, priority metals, benzo(a)pyrene, several volatile organic compounds (VOCs), heavy oil fly ash, coal ash, soot and other substances were calculated in the

\footnotetext{
${ }^{1}$ Retrieved from: http://www.kardiocentr.com (date of access: 07.06.2016).
} 
studies of impacts of chemical pollutants in ambient air on health of the residents who live in the zones of influence of air emissions from stationary and mobile sources. Due to a diverse nature of adverse health effects of these air pollutants, risk assessment was limited to several most important health endpoints: additional mortality, additional respiratory diseases, individual and population carcinogenic risk.

Individual carcinogenic risk (ICR) is an aggravated estimate of the individual risk of development of cancer over the expected lifetime, usually 70 years. For example, ICR $=10^{-4}$ means that one additional malignant neoplasm will develop in a population cohort of 10000 people. Population carcinogenic risk characterizes additional (above background level) number of malignant neoplasms in a given population; this risk is often expressed as the number of cases per year.

Exposure assessment combined Mosecomonitoring data with air dispersion modelling using modern software packages (AERMOD, ISCLT3, CALPUFF, CALINE4, CAL3QHC). These computerized algorithms allow the user to identify exposure pathways from the emission source to the residential areas. Modelling results include the calculation of annual average, daily average and maximum 20-minute concentrations, which can be analysed both in spatial and in temporal dimensions ${ }^{1}$.

Application of air dispersion techniques allowed to minimize the inherent errors of the air quality monitoring network regarding the spatial distribution of air pollution, and to assess exposures to the priority air pollutants more precisely. Modelling results also helped identify air pollution hotspots, calculate the resultant health risks and attribute these risks to particular stationary or mobile sources. In the result, the relative inputs of the largest industrial emission sources (including automobiles) to the existing health risks were calculated. These inputs were later used in to propose the most effective risk management solutions.

Air dispersion modelling of automobile traffic emissions and subsequent health risk assessment was performed for 74 municipal districts of

\footnotetext{
1 U.S. Environmental Protection Agency. (1999). Residual Risk Report to Congress. Office of Air Quality Planning and Standards, Washington, D.C., EPA/453/R-99/001; U.S. Environmental Protection Agency. (July 1999). Dispersion Modelling of Toxic Pollutants in Urban Areas, Guidance, Methodology and Example Applications, EPA/OAQPS, Research Triangle Park, NC, EPA-454/R-99-021; U.S. Environmental Protection Agency. (2003). Guideline on Air Quality Models. Federal Register 40 CFR Part 51 Appendix W.
}

Moscow with total area 400 square kilometres and population about 3.5 million. The relative inputs of different carcinogenic substances to total carcinogenic risk were estimated. These were: $36.8 \%$ for benzene, $26 \%$ for 1,3-butadiene, $25.6 \%$ for formaldehyde, $7.8 \%$ for acetaldehyde and $3.4 \%$ for soot. These five substances accounted for $99.4 \%$ of carcinogenic risk from mobile sources of air pollution in Moscow. The cumulative input of other carcinogenic substances (lead, styrene, benzo(a)pyrene, cadmium and nickel) in total individual carcinogenic risk was less than $0.6 \%$.

Average levels of individual carcinogenic risk from mobile sources of air pollution for the study area $\left(400 \mathrm{~km}^{2}\right)$ varied from $3.0 \times 10^{-4}$ to $6.5 \times 10^{-4}$ which is typical for most megalopolises in the economically developed countries. According to widely accepted medical and social classification of health risks, these values are considered moderate. However, the carcinogenic risks in some districts may exceed the threshold of $10^{-3}$ which is regarded as unacceptable (intolerable) risk. In this case, risk reduction efforts shall be immediately required. According to the cited study, more than 200,000 people (out of 3.5 million included in the study) live in the territories with unacceptably high carcinogenic risks. Another 340,000 people live in the territories where risk levels approach this dangerous threshold, while 1.3 million people live in the territories with moderate risk levels and 1.5 million people live in the territories where the risks are slightly above the $\times 10^{-4}$ threshold, which is considered "acceptable" (tolerable).

The study of carcinogenic risks in Moscow also considered population risks, expressed as the expected weighted average number of additional malignant neoplasms above the background levels, which could be attributed directly to air emissions from automobiles. These levels were as follows: about 6 cases per year among those 200,000 people who live in the conditions of intolerable risks, 4 cases for year for those 340,000 people who live under the risks approaching this intolerable threshold; 8 cases per year for those 1,3 million people who live in the territories with moderate risks and 5 cases per year for those 1.5 million who live in the conditions of acceptable risks. The total population carcinogenic risk for 3.5 million people included in the study was 23 cases per year.

Unlike carcinogenic risks, where exposure assessment was based on air dispersion modelling, $\mathrm{PM}_{10}$ risks were calculated using only the measurement data from Mosecomonitoring network. Individual mortality risk levels, attributed to $\mathrm{PM}_{10}$, varied from $1.6 \times 10^{-4}$ to $2.5 \times 10^{-4}$ per year. These risks corresponded to less than a $2 \%$ increase in 
total mortality. Similar results were produced by calculations of risks of daily mortality attributed to $\mathrm{PM}_{10}$. Relative excess daily mortality attributed to $\mathrm{PM}_{10}$ varied between $2 \%$ and $3 \%$. The relative risks of daily mortality attributed to ozone pollution were calculated using 8-hour average ozone concentrations and varied between $1.5 \%$ and $2 \%$. The simulation of relationship between mortality, air temperature and air pollution in Moscow showed that about $70 \%$ of additional deaths from all non-accidental causes were explained by prolonged exposure to high temperatures and the remaining $30 \%$ were attributed to the effects of air pollution in the conditions of heat stress, that is, to the combined effects of these two risk factors. Let us compare daily additional mortality rates attributed to the following two environmental factors: (1) the 44-day-long episode of extreme heat and air pollution in Moscow in 2010 and (2) average additional mortality attributed to $\mathrm{PM}_{10}$ pollution in Moscow in the summer of 2015. Out estimates were 159 deaths in the first case and 6 deaths in the second.

Air quality in Moscow and the resultant health risks represent an important piece of information for the WHO, because this organization periodically reviews the scientific evidence and revises its recommendations for air quality standards. The latest WHO recommendations were issued in 2005 and contained air quality standards for the most important air pollutants ${ }^{1}$.

WHO uses daily mean $\mathrm{PM}_{10}$ levels and $\mathrm{PM}_{2.5}$ annual level to compare air quality in various cities of the world. $\mathrm{PM}_{10}$ levels in Moscow are close to those in Paris, Rome, and considerably lower than those in Asia and Latin America (New Delhi, Madras, Calcutta, Cairo, Dacca, Beijing, Shanghai, Mexico, Manila, Bangkok, Seoul, Karachi and some other megalopolises ${ }^{2}$. However, several recent studies suggested that there is no margin of safety, or a lower threshold, below which $\mathrm{PM}_{10}$ poses zero health risk. EC program "Clean Air for Europe" (2013) sponsored two projects of European Bureau of WHO: (a) Review of evidence on health aspects of air pollution (REVIHAAP) ${ }^{3}$ and (b) Health risks

\footnotetext{
${ }^{1}$ WHO (2006). Air Quality Guidelines Global Update 2005. Retrieved from: http://www.euro.who.int/_data/assets/pdf_ file/0005/78638/E90038.pdf (date of access: 07.06.2016).

2 WHO's Ambient Air Pollution database-Update 2014. Retrieved from: http://www.who.int/phe/health_topics/ outdoorair/databases/AAP_database_results_2014.pdf (date of access: 07.06.2016)

${ }^{3}$ World Health Organization. (2013). Review of evidence on health aspects of air pollution - REVIHAAP project. Technical Report, 302. Retieved from: http://www.euro.who.int/_data/
}

of air pollution in Europe (HRAPIE) ${ }^{4}$. The recommendations, published by these two projects, were based on the latest scientific evidence of the health effects of particulate matter, ground-level ozone, $\mathrm{NO}_{2}, \mathrm{SO}_{2}$, selected metals (arsenic, cadmium, nickel, lead and mercury), polycyclic aromatic hydrocarbons, and all air pollutants regulated by EU Directives 2008/50/EC ${ }^{5}$ and 2001/81/ EC $^{6}$. The main conclusion from these recommendations may be summarized as follows: more than $80 \%$ of European population, including those who live in EU, currently live in the cities where PM levels exceed the standards recommended by the $\mathrm{WHO}^{7}$. Health risks attributed to particulate matter in the ambient air should be minimized in the course of implementation of the most efficient air quality management strategies, because even relatively low PM levels are associated with considerable health risks.

It could be useful to change locations of automatic air quality monitoring stations to gain more precise data on air quality in residential areas. Some stations should be moved away from the motorways and placed inside the residential districts. This is recommended in the first place for those stations which perform continuous monitoring of such priority pollutants as $\mathrm{PM}_{10}$ and $\mathrm{NO}_{2}$.

Children are especially vulnerable to health risks posed by air pollution. We recommend conducting a cross-sectional epidemiologic study in individual pediatric districts in order to better understand the emerging hotspots of excess

assets/pdf_file/0004/193108/REVIHAAP-Final-technicalreport-final-version.pdf (date of access: 07.06.2016).

4 World Health Organization. (2013). Health risks of air pollution in Europe - HRAPIE project. Recommendations for concentration-response functions for cost-benefit analysis of particulate matter, ozone and nitrogen dioxide. Retrieved from: http://www.euro.who.int/_data/assets/pdf_file/0006/238956/ Health-risks-of-air-pollution-in-Europe-HRAPIE-project,Recommendations-for-concentrationresponse-functionsfor-costbenefit-analysis-of-particulate-matter,-ozone-andnitrogen-dioxide.pdf (date of access: 07.06.2016).

${ }^{5}$ Directive 2008/50/EC of the European Parliament and of the Council of 21 May 2008 on ambient air quality and cleaner air for Europe.

${ }^{6}$ Directive 2001/81/EC of The European Parliament and of the Council of 23 October 2001 on National Emission Ceilings for Certain Atmospheric Pollutants.

7 World Health Organization. (2013). Health risks of air pollution in Europe - HRAPIE project. Recommendations for concentration-response functions for cost-benefit analysis of particulate matter, ozone and nitrogen dioxide. Retrieved from: http://www.euro.who.int/_data/assets/pdf_file/0006/238956/ Health-risks-of-air-pollution-in-Europe-HRAPIE-project,Recommendations-for-concentrationresponse-functionsfor-costbenefit-analysis-of-particulate-matter,-ozone-andnitrogen-dioxide.pdf (date of access: 07.06.2016). 
morbidity among children. A standard protocol is currently being used for questioning and medical examination of children to better estimate actual prevalence of bronchial asthma among children. Utilization of such protocols will help identify the actual prevalence of bronchial asthma and quantify health risks attributed to air pollution. Health risk assessment could be used to justify environmental protection activities in the most heavily polluted areas, and to identify priority sources of air pollutants accountable for health risk.

Prevention of adverse health effects of air pollution calls for the implementation of sound scientific methods of risk management based on modern air quality control requirements. Modern risk management methods should be used during the planning of residential development, construction of new residential districts, and development of transportation network in megalopolises.

\section{Acknowledgements}

The research has been supported by the Grant program from Russian Science Foundation (Project No. 16-18-10324. "Human in Megalopolis: Economic, Demographic and Ecological Specificities»).

\section{References}

1. Woodward, A., Smith, K. R., Campbell-Lendrum, D., Chadee, D. D., Honda, Y., Qiyong, L., Olwoch, J., Revich, B., Saverborn, R., Chafe, Z., Confalonieri, U. \& Haines, A. (2014, April 5). Climate change and health: on the latest IPCC report. Comment. The Lancet, 383, 9924, 1185-1189.

2. Mage, D., Ozolins, J., Peterson, P., Webster, A., Orthofer, R., Wandeweerd, V. \& Gwynne, M. (1996). Urban air pollution in megacities of the world. Atmospheric Environment, 30(5), 681-686.

3. Molina, M. J. \& Molina, L.T. (2004). Megacities and atmospheric pollution, Journal of the Air \& Waste Management Association, 54(6), 644-680.

4. Folberth, G. A., Butler, T. M., Collins, W. J. \& Rumbold, S. T. (2015). Megacities and climate change - a brief overview. Environmental Pollution, 203(5), 235-242.

5. Khan, O. A. \& Pappas, G. (Eds.). (2011). Megacities and global health. Washington, D.C.: American Public Health Association, 316.

6. Pervin, T., Gerdtham, U-G. \& Lyttkens, C. H. (2008). Societal costs of air pollution-related health hazards: A review of methods and results. Cost Effectiveness and Resource Allocation, 6(19).

7. Northridge, M. E., Sclar, E. D. \& Biswas, P. (2003, December). Sorting out the connections between the built environment and health: A conceptual framework for navigating pathways and planning healthy cities. Journal of urban health: Bulletin of the New York Academy of medicine, 80(4), 556-568.

8. Miraglia, S. G., Saldiva, P. H. N. \& Böhm, G. M. (2005). An evaluation of air pollution health impacts and costs in Sao Paulo, Brazil. Environmental management, 35(5), 667-676.

9. Kvasha, E. A. \& Kharkova, T. L. (2008). Moskovskiy fenomen smertnosti - uroki dlya Rossii [Moscow mortality phenomenon: Lessons for Russia]. Voprosy statistiki [Questions of statistics], 9, 6-18.

10. Kvasha, E. A. \& Kharkova, T. L. (2009). Rossiyane i moskvichi ne ravny pered litsom smerti [Russians and Muscovites are not equal in the face of death]. Demoskop Weekly, 369-370.

11. Kulbachevsky, A. O. (2015). Doklad o sostoyanii okruzhayushchey sredy v gorode Moskve $v 2014 \mathrm{~g}$. [State of the environment in Moscow in 2014, Annual Report]. Moscow, Departament prirodopol'zovanija i ohrany okruzhajushhej sredy goroda Moskvy [Department of Natural Resources and Environmental Protection of Moscow City]; NIA-Priroda, 382.

12. Revich, B. A. (1995). Zagryaznenie atmosfernogo vozduha i rasprostranennost bronkhialnoy astmy sredi detskogo naseleniya Moskvy [Air pollution and prevalence of bronchial asthma among children in Moscow]. Meditsina truda $i$ promyshlennaya ekologiya [Occupational health and industrial ecology], 5, 15-19.

13. Pope, C. A., Burnett, R. T., Thurston, G. D., Thun, M. J., Calle, E. E., Krewski, D. \& Godleski, J. J. (2004). Cardiovascular mortality and long-term exposure to particulate air pollution: epidemiological evidence of general pathoohsiological pathways of disease. Circulation, 109(1), 71-77.

14. Allen, R. W., Adar, S. D., Avol, E., Cohen, M., Curl, C. L. \& Larson, T. (2012). Modeling the residential infiltration of outdoor PM2/5 in multi-ethnic study of atherosclerosis and air pollution (MESA Air). Environmental Health Perspectives, 120(6), 824-830.

15. Abbey, D. E. et al. (1995). Estimated long-term ambient concentrations of PM10 and development of respiratory symptoms in a nonsmoking population. International Archives for Occupational and Environmental Health, 50(2), 139-152.

16. Peters, A. et al. (2000). Associations between mortality and air pollution in central Europe. Environmental Health Perspectives, 108(4), 283-287.

17. Schindler, C. et al. (2009). Improvements in PM10 exposure and reduced rates of respiratory symptoms in a cohort of Swiss adults (SAPALDIA). American Journal of Respiratory and Critical Care Medicine, 179(7), 579-587.

18. Pope, C. A. 3rd et al. (2011). Lung cancer and cardiovascular disease mortality associated with ambient air pollution and cigarette smoke: shape of the exposure-response relationships. Environmental Health Rerspectives, 119(11), 1616-1621.

19. Lepeule, J. et al. (2012). Chronic exposure to fine particles and mortality: an extended follow-up of the Harvard Six City study from 1974 to 2009. Environmental Health Perspectives, 120(7), 965-970. 
20. Lim, S. S. et al. (2012). A comparative risk assessment of burden of disease and injury attributable to 67 risk factors and risk factor clusters in 21 regions, 1990-2010: a systematic analysis for the Global Burden of Disease Study 2010. The Lancet, 380, 9859, 2224-2260.

21. Samoli, E. et al. (2013). Associations between fine and coarse particles and mortality in Mediterranean cities: results from the MED-PARTICLES project. Environmental Health Perspectives, 121(8), 932-938.

22. Eroshina, K., Wilkinson, P. \& McKee, M. (2013). Rol ekologicheskikh i sotsialnykh faktorov v vozniknovenii zabolevaniy organov dykhatelnykh putey u detey mladshego shkolnogo vozrasta g. Moskvy [The role of environmental and social factors in occurrence of respiratory diseases among primary school students in Moscow]. Medicina [Medicine], 3, 57-71.

23. Zditovetskaya, N. A. (1998). Respiratornaya karta Moskvy [Respiratory map of Moscow]. Avtoref. dis. kand. med. nauk. [Published summery of $\mathrm{PhD}$ thesis in Medicine]. Moscow, 24.

24. Tirsi, O. R. (2004). Vliyanie faktorov okruzhazhushhey sredy i klimaticheskikh usloviy na techenie bronkhialnoy astmy u detey i podrostkov Moskvy i Moskovskoy oblasti [The influence of environmental factors and climatic conditions on development of bronchial asthma of children and adolescents in Moscow and Moscow Region] . Avtoref. dis. kand. med. nauk. [Published summery of $\mathrm{PhD}$ thesis in Medicine], Moscow, 23.

25. Tselykovskaya, N. A. (2000). Otsenka vliyaniya kompleksa sotsialnykh, gigienicheskikh $i$ mediko-biologicheskikh faktorov na sostoyanie zdorovya doshkolnikov g. Moskvy [Assessment of influence of several social, hygienic, medical and biological factors on health status of preschool children in Moscow]. Avtoref. dis. kand. med. nauk. [Published summery of $\mathrm{PhD}$ thesis in Medicine], Moscow, 24.

26. Sidelnikova, N. Yu. (2016). Ekologo-fiziologicheskaya otsenka adaptatsii mladshikh shkolnikov v usloviyakh stolichnogo megapolisa [Environmental and physiological assessment of adaptation of primary school students in the conditions of capital megalopolis]. Avtoref. dis. kand. med. nauk. [Published summery of PhD thesis in Medicine], Moscow, 24.

27. Katsouyanni, K., Touloumi, G., Samoli, E. et al. (2001). Confounding and effect modification in the short-term effects of ambient particles on total mortality: results from 29 European cities within the APHEA2 project. Epidemiology, 12(5), $521-531$

28. Filleul, L, Cassadou, S, Médina, S, et al. (2006). The relation between temperature, ozone, and mortality in nine French cities during the heat wave of 2003. Environmental Health Perspective, 114, 1344-1347.

29. Vandentorren, S, Suzan, F, Medina, S, et al. (2004). Mortality in 13 French cities during the August 2003 heat wave. American Journal of Public Health, 94, 1518-1520.

30. Revich, B. A., Shaposhnikov, D. A. \& Semutnikova, E. G. (2008). Klimaticheskie usloviya i kachestvo atmosfernogo vozdukha kak faktory riska smertnosti naseleniya Moskvy v 2000-2006 gg. [Climatic conditions and air quality as a risk factor for premature mortality in Moscow in 2000-2006]. Meditsina truda i promyshlennaya ekologiya [Occupational health and industrial ecology], 9, 29-35.

31. Shaposhnikov, D., Revich, B., Bellander, T., Bedada, G., Bottai, M., Kharkova, T, Kvasha, E, Lezina, E, Lind, T., Semutnikova, E. \& Pershagen, G. (2014). Heat Wave and Wildfire Air Pollution related Mortality in the Summer of 2010 in Moscow. Epidemiology, 25(3), 359-364.

32. Porfiriev, B. N. (2013). Ekonomicheskaya otsenka lyudskikh poter v rezultate chrezvychaynykh situatsiy [Economic assessment of population loss in emergency situations]. Voprosy ekonomiki [Questions of economics], 1, 48-68.

\section{Authors}

Boris Aleksandrovich Revich - Doctor of Medicine, Professor, Head of the Laboratory of Environmental Health, Institute of Economic Forecasting of RAS (47, Nakhimovsky Ave., Moscow, 117418, Russian Federation; e-mail: brevich@ yandex.ru).

Simon Levanovich Avaliani - Doctor of Medicine, Professor, Department of Hygiene, Russian Medical Academy of Advanced Training (2/1, bld. 1, Barrikadnaya St., Moscow, 125993, Russian Federation; e-mail:savaliani@mail.ru).

Gregory John Simons - PhD in Medicine, Senior Researcher, Centre for Russian and Eurasian Studies of Uppsala University (Sweden, SE 75120, Uppsala, Gamla torget, 3, ven III; e-mail: greg.simons@ucrs.uu.se). 